\title{
Nectar of the Gods: A salute to maple syrup
}

othing says springtime in Canada like maple syrup. As the top producer of the sweet stuff worldwide, it has become a national calling card, a poignant symbol of our culture. Even our National flag sports the mighty maple, promising gastronomic goodness for all. In 2008, Canada produced around 27 million litres of syrup, to the tune of over \$263 million. Ninety percent of this syrup came from Quebec, with Ontario and New Brunswick a distant second and third in production. The natural distribution of the eponymous sugar maple (Acer saccharum), combined with the climatic conditions required for sap collection ensure a northeastern monopoly.

Although the Ontario Ministry of Agriculture, Food and Rural Affairs (OMAFRA) suggests that a sugar bush operation would need a minimum of about 1000 taps to achieve profitability, this should by no means discourage the small operator or hobbyist from making the most of their woodlot and sweetening up their lives in the process. Maple syrup production can actually be quite simple on a small scale. The important investments are time and care; the reward is liquid gold.

Depending on annual and local weather conditions, maple sap collection can begin anywhere between midFebruary and early March and last from four to six weeks. The winter carbohydrate stores in the tree roots are coaxed slowly up the stem via the sapwood when cool nights (around $-5^{\circ} \mathrm{C}$ ) are followed by warmer days $\left(2-7^{\circ} \mathrm{C}\right)$. Early sap flow is generally the sweetest, so it pays to watch the weather and start as early as possible. When the tree's buds begin to swell, the flavour of the sap changes and tapping season is over.

A tree can be tapped once it reaches $25 \mathrm{~cm}$ diameter at breast-height. A sugar maple will reach this size anywhere between 20 and 80 years of age, depending on site conditions and stand management. A single tree can support from one to four taps, depending on its size and health. Taps should be placed a minimum of $15 \mathrm{~cm}$ away from each

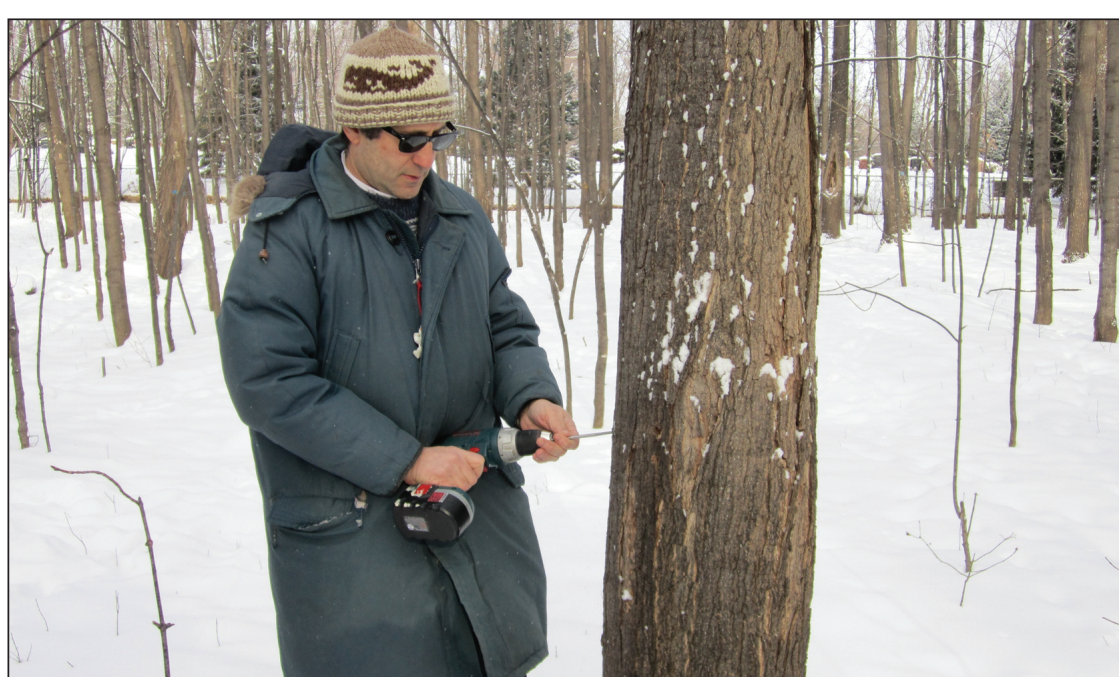

Mike Rosen, vice-chair of the Ottawa Valley Section, demonstrates the proper technique for tapping a sugar maple.

other and from recent tapholes. A healthy maple in a well-managed stand can produce, on average 30-50 litres of sap daily during tapping season, and can be tapped annually for decades.

While commercial operations use fixed plastic tubing and vacuum suction to coordinate collection from $100-200$ tapholes per hectare over large areas, the old-fashion bucket method may be more suitable for the backyard bush on a small lot. All you need is a drill, collection buckets (with lids, to keep the snow, rain and critters out) and metal spiles. A spile is the tap that's inserted in the hole to allow the sap to flow to the bucket. It is important to empty the buckets daily to prevent spoiling of the fresh sap. Once collected, the sap can be frozen to preserve until you're ready to boil it. The fresh sap contains approximately $1-4 \%$ sugar. By definition in Canada, maple syrup has at least $66 \%$ sugar content, so evaporation is used to condense the watery sap to the darker, viscous pancake topper we all know and love. For every litre of syrup produced, 30-40 litres of water are evaporated. Evaporation can be done in a large pan over a wood fire, or on a gas stove.

There are a number of methods to determine when the sap has become
For more information on maple syrup or on managing your own sugar bush, visit the following sites

- Ontario Ministry of Agriculture Farms and Rural Affairs www.omafra.gov.on.ca

- La Fédération des producteurs acéricoles du Québec www.siropderable.ca

- Rideau Valley Conservation's Landowner Resource Centre www.lrconline.com

- Ontario Maple Syrup Producers Association www.ontariomaple.com

- New Brunswick Maple Syrup Association http://maple.infor.ca

- Cornell Sugar Maple Research and Extension Program

http://maple.dnr.cornell.edu 
maple syrup. At $66 \%$ sugar content, maple sap boils at $4^{\circ} \mathrm{C}$ above the boiling temperature of water. By monitoring with a thermometer (calibrated for water boiling temperature at your elevation) you can track the sugar concentration. There are also two different instruments that may be used specifically to determine sugar concentration. The first, a hydrometer, uses the density of the sap to derive sugar concentration, while the other, a refractometer uses light refraction through the liquid. If you plan to sell your product as "maple
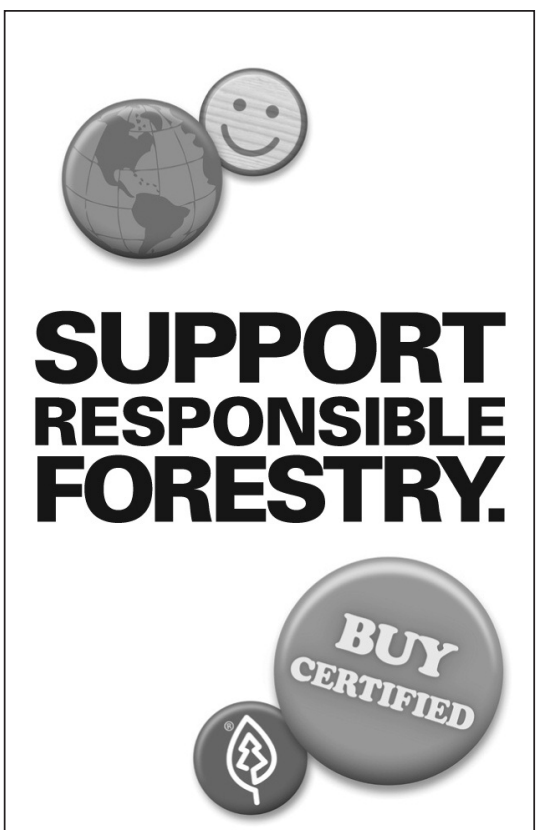

When you consider that only $10 \%$ of the world's forests are certified, we have a long way to go. The good news is that there are a number of credible forest certification programs. And each one, including SFI, encourages responsible forestry. For more on forest certification and what you can do, visit www.sfiprogram.org. syrup", Federal regulations require you meet the $66 \%$ concentration standard. If, however you intend it purely for your own table, a rough guess and a taste test might suffice. Once evaporated, the syrup should be filtered to remove any particulates, and stored in the refrigerator or freezer.

The final product can be classified and graded according to National standards based on its density and translucency. The extra light and light syrups are the highest grades, and are most coveted for table use and for products such as maple sugar and maple butter. The lower grades are the dark and amber syrups. These grades have a stronger flavour and are recommended for use in cooking. The high-grade syrup is often from sap collected earlier in the season.

Needless to say, maple trees need plenty of sunlight to produce the sweet sugars that we enjoy so much. Good stand management can help improve tree growth and increase sap yield from your sugar bush. By removing diseased or overmature trees you will open space to encourage younger trees to reach tappable age, and help established trees increase their canopy and sap production. Highly intensive management might have you remove any and all non-maple species from your stand such as fir, beech, and basswood, and though sugar maple can certainly thrive in pure stands, this approach would impact other values of your forest, decreasing biodiversity and limiting wildlife habitat for example.
Prior to European settlement, First Nations people had learned to collect and refine maple sap using hatchets and hot rocks. Though the technology has advanced, the process has changed little. It's just sweet and simple. So if you decide to venture out into the woods with a spile and bucket this year, be sure to see the job through to its sticky end. It's worth every drop.

Mike Halferty

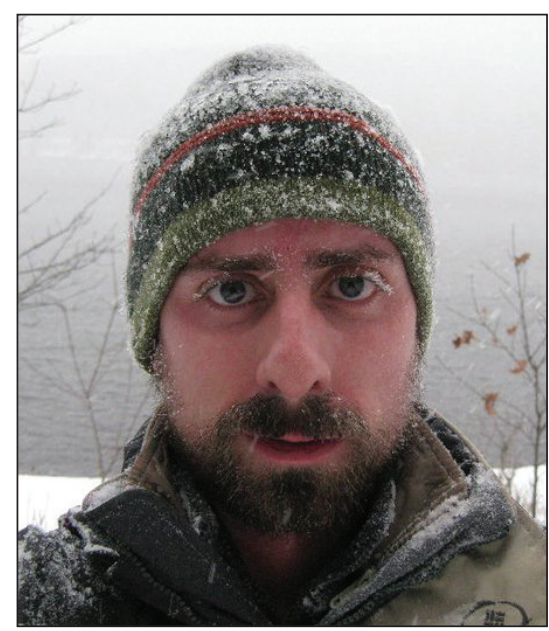

Mike Halferty, Forestry Extension Coordinator, CIF/IFC-FRP. [Ed's Note: Mike's internship has finished and this is his last article for the Chronicle as the Forestry Extension Coordinator. He has been a very positive contributor to the CIF/IFC National team and we wish him continued success in his new position as Forestry Programs Manager with the Ontario Forestry Association]

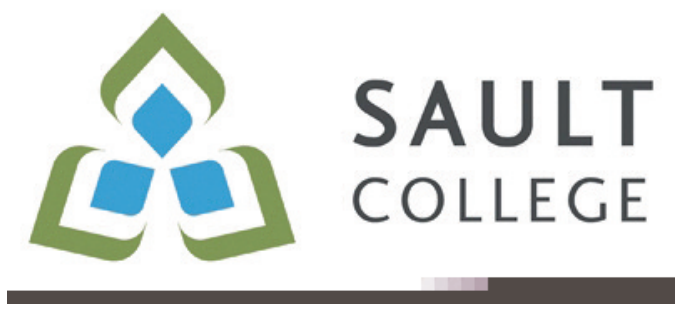

\section{A Canadian Institute of Forestry/Institut forestier du Canada}

Corporate Sustaining Member/Membre corporatif commanditaire 

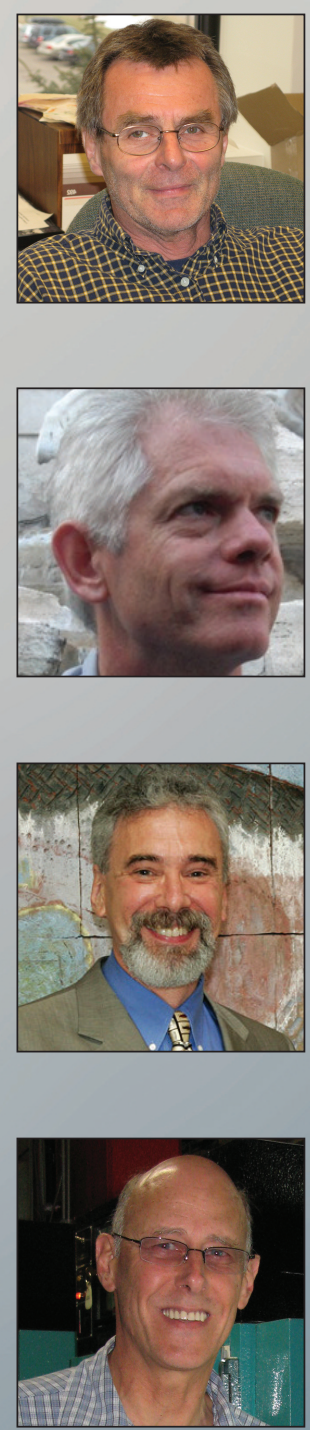

Conserving Canada's Forest Genetic Resources Dale Simpson

Manager, National Tree Seed Centre -

Natural Resources Canada

May 11, 2011

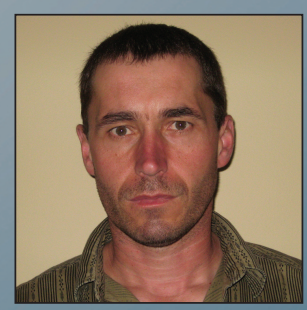
Alex Mosseler April 6, 2011

Sex, Stress, and Suppression: Ecology and management of the brown spruce longhorn beetle

Jon Sweeney Canadian Forest Service - Atlantic Forestry Centre April 20, 2011

Overcoming regulatory barriers: The registration and Christopher Lucarotti May 4, 2011
Brown spruce longhorn beetle risk modeling, impacts, and best management practices Wayne MacKinnon Forestry Officer - Canadian Forest Service Atlantic Forestry Centre May 18, 2011

Native willows: biomass for a bio-economy and ecological restoration

Research Scientist - Canadian Forest Service - Atlantic Forestry Centre

Research Scientist - Forest Insect Ecology and Management commercialization of a biological control product for the balsam fir sawfly Research Scientist - Canadian Forest Service - Atlantic Forestry Centre

All electronic lectures are free. Your consideration of CIF/IFC membership would be appreciated.

www.cif-ifc.org/en/e-lecture To become a CIF/IFC member: www.cififc.org/en/registration 10:30 a.m. PST; 1:30 p.m. EST FOR ADDITIONAL INFORMATION OR TO REGISTER, CONTACT: Matt Meade Canadian Institute of Forestry/ Forestry Research Partnership E-mail: mmeade@cif-ifc.org or

Tel: 705-744-1715 ext.595 Fax: 705-744-1716 